\title{
UTILIZING REFLECTIVE TEACHING STRATEGIES TO DEVELOP EFL IRAQI UNIVERSITY STUDENTS' WRITING ABILITY
}

\author{
Instructor : Tamara AdilMekki \\ College of Education for Human Sciences -Ibn Rushd-University of Baghdad
}

DOI: $10.37648 / \mathrm{ijrssh} . v 10 \mathrm{i} 02.020$

Received:1 $7^{\text {th }}$ February, 2020; Accepted:06 ${ }^{\text {th }}$ March, 2020; Published: 29th March, 2020

\section{ABSTRACT}

Most EFL researchers have arrived at the essential fact that when teaching is taken into consideration, it is important to conceive that EFL teachers cannot teach successfully and EFL students cannot learn by obeying routinized and traditional practices, which ultimately decline teaching and learning to a mechanical activity. Yet, when EFL espouse a new reflective standpoint, they are able to reflect upon the difficulties and problems in the learning process and discern how such difficulties and problems are connected with their instructive and social settings. Reflective teaching in particular tends to enhance students' abilities in English language learning since it gets students more involved in their educational problems and help them to find solutions to such problems.

This paper aims to show the effect of utilizing reflective teaching strategies on $3^{\text {rd }}$ year students' development in writing essays. 24 students of third year (distributed equally into two groups control and experimental) are chosen to be the sample of the study. Two instruments are utilized to detect students' improvement: observation and tests (pretest and posttest).

The study concludes that students' reflection on one another's writing directly and indirectly motivates them to participate in discussions and arguments which consolidate their critical thinking while writing their essays. Further, experimental group, who appeal to reflective teaching strategies, have shown to perform better than control group in expressing their ideas and opinions in their essays.

Key words: reflection, reflective teaching, reflective teaching strategies, writing abilities 


\section{INTRODUCTION}

Supporters of reflective teaching believe that experience by itself is deficient for proficient development, unless this experience gets supplemented by reflection as the latter seems to be a more powerful incentive for progress. Then, teaching development can be attained through rebuilding of experience.

Reflection is seen as the system in which one can learn from his/her knowledge and understood as a thoughtful thinking about an act with an interpretation to its development. Reflective teaching then is concerned with looking at "what you do in the classroom, thinking about why you do it and thinking about if it works". That is, it is a way of "selfobservation and peer-evaluation"(Powell, 1985:77). For Richards (1990:91), reflection is a crucial constituent of teacher improvement. In this sense, self-investigation and "critical thinking can help teachers move from a level where they may be guided largely by impulse, intuition, or routine, to a level where their actions are guided by reflection and critical thinking". Thus, reflection encompasses stimulating practices that embrace reflective periodicals, including "dialog journals, peer reflection, diaries, learning $\operatorname{logs}$ and audio-video recordings".

The literature available on ESL/EFL teaching has shown that reflective practice day after day has been becoming a prevailing pattern in ESL/ EFL teaching programs through the world. The significance of this type of teaching emanates from the fact that reflective practice allows ESL/EFL teachers to "think about what, how and why they do it", it enables them "to step out of routine action and make adaptations to match the needs of the learners" (Mohammad, 2019:2). On their part, reflective exercise enables students to reflect on one another's performance in language settings.

Thus, this paper is devoted to the presentation of the most practical reflective teaching strategies that can be utilized to enhance students' writing ability and the effect of these strategies on students' development in this ability.

\section{REFLECTIVE TEACHING}

Teaching process can be defined as "the action of a person imparting skill or knowledge or giving instruction, the job of a person who teaches" (Moore, 2007: 5). It is an attempt to help students in getting or shifting some skill, information, model, viewpoint, or indebtedness (Clark and Starr, 1986: 23). For Bruner (1966: 1), teaching should be best labeled as "instruction" employed as "an effort to assist or shape growth". In this respect, teachers are required to be more involved in all aspects (i.e. cognitive, emotional, social and physical) of learners' improvement.

Focusing on teaching procedure in EFL classroom, Richards and Lockhart (1996:1) proclaim that in reflective teaching "teachers collect data about teaching, examine their attitudes, beliefs, assumptions, and teaching practices, and use the information obtained as a basis for critical reflection about teaching". Or as Dewey (1933:7) puts it, to reflect means to reinvestigate what has gone one in order to produce the understandable interpretations "which are the capital stock for intelligent dealing with further experiences". Put simply, reflective teaching is the core of rational organization and of the self-controlled mind.

In line with Dewey's view, Schon (1996:77) identifies reflective teaching as a "critical process in refining one's artistry or craft in a specific discipline". Practically, it is a method for beginners in a discipline to identify association between their own specific teachings and those of effective specialists. In this sense, reflective teaching is concerned with attentively considering one's own involvements in putting on "knowledge to teaching while being coached by professionals in the discipline".

Schon's (1996) view is supported byZeichner and Liston (1996:78) who confirm that reflective teaching entails "a recognition, examination, and rumination 
over the implications of one's beliefs, experiences, attitudes, knowledge, and values as well as the opportunities and constraints provided by the social conditions in which the teacher works." Therefore, reflective teaching is significant in the sense that it revolves around the connection between a learner's way of thinking and action and the connection between his/her teacher and his/her affiliation in society (Bailey et al., 2001: 37).

In fact, a reflective teacher "takes responsibility for his/her own professional development" (Zeichner and Liston, 1996: 56). Placed another way, a reflective teacher must reflect even on "unplanned and unpredictable events in teaching because teaching, even under the best conditions, always involves unintended as well as intended outcomes" (ibid).

In brief, reflective teaching often identifies a teacher as an "active initiator and executor of improvements and changes in his/her classroom", meanwhile; he/she takes responsibility for his/her own participation within the setting of the instructional institute and society. For this reason, numerous approaches concerning reflective teaching have been developed to involve activities such as "peer observation, written accounts of experiences, self-report, autobiographies, journal writing and students feedback" (Bailey, 1990:98).

\section{IMPORTANCE OF REFLECTIVE TEACHING}

Because of its theoretical and practical significance, York et al. (2006:189) recognize a number of possible advantages of reflective teaching.

Firstly, reflective teaching can provide fresh teachers with the regulation to accept new roles and provide skilled teachers with incessant learning. In other words, it can "bridge the gap between theory and practice, offer considerations of multiple perspectives, and provide productive engagement of conflict and knowledge for immediate action".
Secondly, reflective teaching also can offer teachers entrenched formative evaluation to supply feedback to students and teachers over the progression of teaching. It can also provide development "in cultural competence, and understanding of role and identity". Thus, it can preserve "individual and collective efficacy, strong connections among staff, great professionalism and voice and less external mandates". Here, teachers are required to know that "reflection is a dynamic process", which can go through consecutive sequences which can ultimately result in "higherquality teaching". Fox (2004: 90) argues that the principal advantage of reflective teaching for teachers of English is a "deeper understanding of their own teaching style and ultimately, greater effectiveness as a teacher".

Thirdly, with reference to viewing reflective teaching as artistry and its diversity in applying its theories to classroom teaching, Harris (1998:76) affirms that reflective teaching can be a valuable procedure of "professional development at both the pre-service and in-service levels of teaching". Through getting a better understanding of their own teaching ways through reflective teaching, teachers can recover their efficiency in the classroom.

Fourthly, through the application reflective ideas in their careers, teachers can overcome problems, such as" lack of time, lack of expertise, lack of continuous support and fear of being weak teachers". This is because reflective teaching can offer a possibly "more private, and more manageable professional development alternatives" for teachers who face these problems (worries) (Bailey and Nunan ,1996:88).

Fifthly, fresh and experienced teachers can benefit from being reflective as they are able "think about what they wish to accomplish in the classroom, why they have chosen these goals or those, and how they wish to achieve these goals" (Merryfield, 1993:75). This is due to the fact that reflection activates with one's inclination to inquiry his/her practice, improves with "observing students, 
identifying their needs and ends with action". In this sense, a teacher can adjust his/her "teaching style to match students' learning styles".

Finally, Larrivee and Cooper (2006:98) contend that reflective teaching can "free teachers from routine behavior". They expound that "when teachers teach in a routine fashion, they follow the designated textbooks or teach a lesson in the same way it was taught in the past without an effort to change or innovate". Consequently, becoming a reflective teacher releases one from monotonous act and can lead to more inventive and innovative lessons.

\section{REFLECTIVE TEACHING PHASES}

Studies concerned with reflection have proved that this process is centered upon a cyclic activity (Bartlett 1990:56; Wallace, 1991:90; Taggart and Wilson, 2005:94). This indicates that teachers are supposed to make plan and requirements and act in a way that can ultimately result in effective teaching. Perhaps, the most representative model of reflective process is that of Bartlett's (1990:94) which provides a detailed explanation of reflective teaching. He argues that reflection is a cyclic activity which implies five phases:"mapping, informing, contesting, appraising, and acting"; they provide a systematic method tothe "process of making committed choices as the basis of good teaching". And when teachers resort to reflective method, they may go through the cycle several times.
First, in mapping, teachers start "observing and collecting evidence about their teaching. Observation may consist of tape-recording, using photography, keeping a diary or a journal". Teachers first observe and then reflect on their normal and cognizant activities in the classroom, dialogues with learners, critical occasions during a lesson, "their personal lives as teachers and their beliefs about teaching".

Second,ininforming, teachers reconsider their first record (their maps) and improve them to make sense of them. This phase may take place after a teaching order and it may be made by "the individual teacher or by having a discussion with others" (Wallace, 1991:78).

Third, incontesting, teachers explore assumptive worlds and probe in incongruities and inconsistencies in what teachers act and plan to act.

Fourth, in appraisal, teachers start to connect "the thinking dimension of reflection with the search for teaching in ways that are consistent with their new understanding". In this connection, teachers may inquire themselves "what would be the consequences to teaching" if they changed (Wilson, 1990:98).

Lastly, acting entails "a continuing dialectical relationship exists between the preceding phases and the idea of acting out new ideas about teaching" Bartlett (1990:90). That is, it is presented as a chronological process of reflective teaching as shown in this figure 1. 

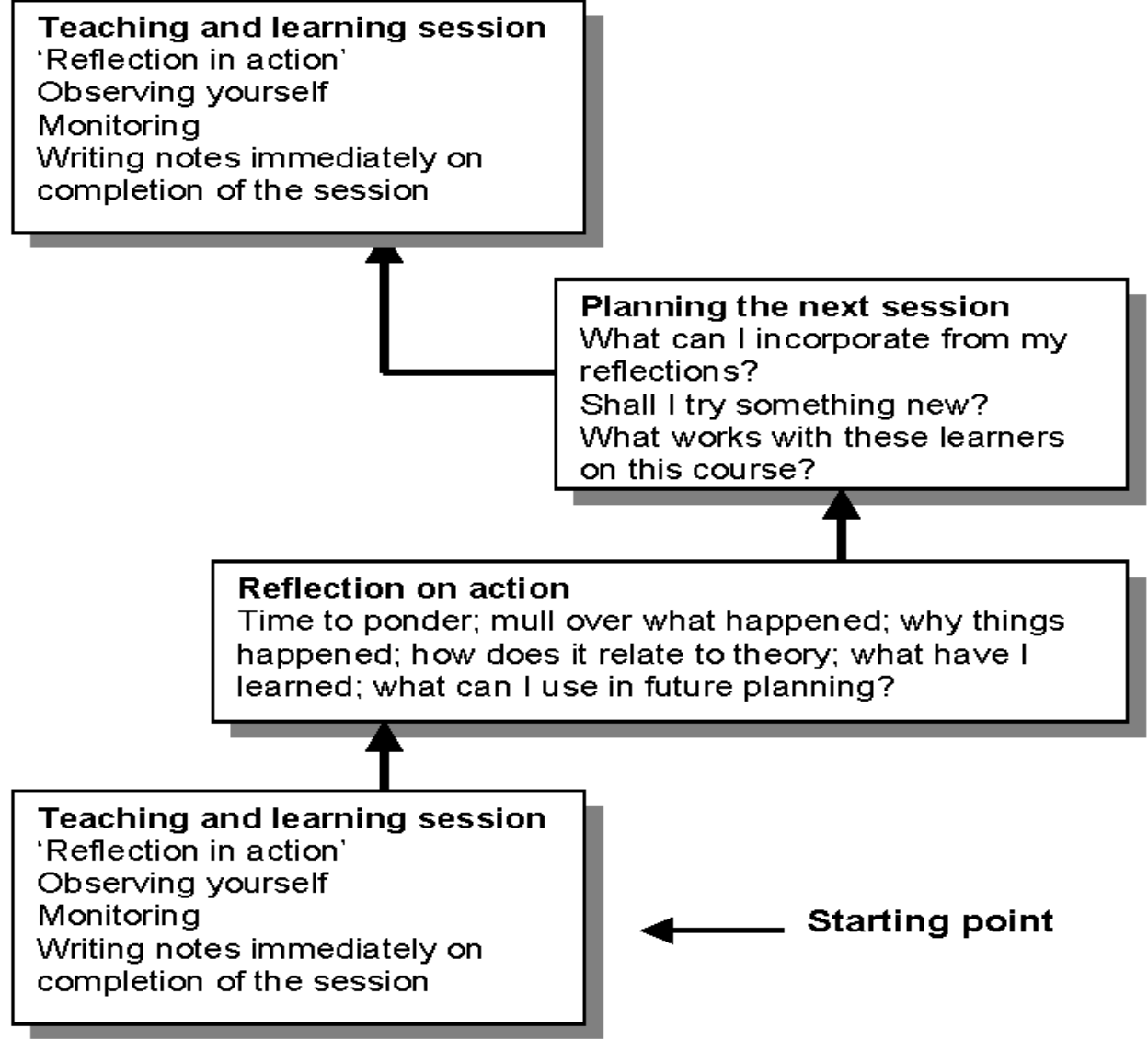

Figure 1: Process of Reflective Teaching (Bartlett (1990)

\section{REFLECTIVE STRATEGIES IN WRITING}

It has been noticed that reflective teaching is a very effective way for teachers, yet reflective teaching strategies and activities can very effective for students. Reflective experience offers students the chance to evaluate their capabilities and to enhance the manner they learn. The essentiality of reflection is that it gives students the chance to objectively reflect on their advancement and critically assess their improvement. Moreover, through reflective method, students can conceive how to adjust their own ability of writing. That is, they can develop a more 'selfguiding and self-governing' way of writing. Reflective teaching can help them to recognize breaches in their writing ability, and consequently, can attain progress and growth in their writing capacities.

One advantageous method of engaging students in the process of reflection is through the utilization of the practices of written accounts which can be developed in terms of various reflective teaching strategies. Based on Powell's (1985) and Hatcher and Bringle's (1996) reflective writing strategies, the following involves the strategies that are employed in this paper and intended to help Iraqi EFL university students improve their writing ability. 


\section{A. Sentence Stem-based responses}

Sentence-stems are effective tools to train students "into thinking and speaking in certain patterns". For example, you can appeal students to "think critically" with the use of phrases associated critical thinking (for example, 'The issue is central since it ...').

\section{B. Layered Text}

A layered text is is linked with multiple things, enabling students to talk about anything in the world. This type of a text includes: "questions students have, opportunities for further inquiry, odd references and allusions that reflect the schema students use to make meaning". In this way, students can "reflect back on anything, from a pre-assessment journal entry that demonstrated their lack of understanding, to a kind of 'marking up' of what they learned when, and from where".

\section{Write-Around}

Write-around is associated with ways available to students to "write asynchronously and collaboratively" and this will help them to reflect on the way a lecture or a lesson goes on one hand, and learn from one another "as each student is able to read other responses before creating theirs."

\section{Sketch}

Sketches allow students to "draw what they think they know how they believe their learning has changed". They tend towards passageway to greater understanding and this is an effective strategy for students that incline to "creative expression, and a non-threatening way for struggling students". This will help, in return, teachers to plan his/her step.

\section{E. Brainstorming}

In brainstorming strategy, students could "take an allotted time to write down everything they remember about a topic. Or, they could brainstorm questions they still have" points that students feel confused and irritated. This strategy actually motivates students to recognize "how what they learned literally connects with what they already know by creating a concept map".

\section{F. Jigsawing}

In complying with Jigsawing strategy, "a task, concept, or something 'larger' is broken down into small puzzles pieces". Moreover, students collaboratively examine" the small puzzle piece, then share out to create the puzzle at large". This unified strategy stimulates "students in groups to gather and share questions they have... in groups, and then choose one question that they weren't able to answer among themselves with the whole class".

\section{METHODOLOGY}

This section presents the method followed in attaining the data analysis and data results which are based on three subsections: (i) a sample of the students involved in the study,(ii) the instrument exploited consisting of pretest and posttests, and (iii) type of method followed in demonstrating the effect of applying reflective strategies to enhance students' writing ability.

\subsection{Sample}

The sample of the study consists of two groups of (24) third year-students of the Department of English, College of Languages , University of Baghdad, divided into (12) students for the experimental group ( being taught to follow reflective teaching strategies) and (12) students for the control group( being taught conventionally and traditionally). Basically, the two groups are equalized in terms of gender variable, the academic level of the mother variable, the academic level of the father variable, age variable, and the subjects' level on the pretest.

\subsection{Instrument and Practical Side}

The main instruments utilized for the data collection comprise two phases: observations of sessions and test (pretest and posttest). Ten sessions (the first for pretest and eight for the application of 
reflective teaching in writing and the last for the posttest) were held (during the $1^{\text {st }}$ semester for the academic year 2018-2019) for the students' employment of the reflective strategies while writing their essays. The researcher in the second session explains the techniques by which the reflective strategies (mentioned above) can be implemented. At the end of each session, the researcher selects a topic and asks her students to write an essay about it.

Meanwhile, she discusses some details and ideas concerning the chosen topic, allowing students to participate in collaborative discussions and arguments. Students are exhorted to get involved into thinking and writing (thinking critically) utilizing phrases linked to critical thinking such as "The topic is important because it...".

Next, students are brainstormed to follow the strategy of a layered text which enables them to talk about things in society. This in return would help them to trigger the schema they employ to produce meaning. The reflective strategy of 'Write-around' allows students to write sequentially and cooperatively and thus to reflect on what the chosen student has written. This way may help students to learn from one another since each student is supposed to read his/her assignment before his classmates.

Sketches (fourth reflective strategy) enable students to "draw what they think they know how they believe their learning has changed". They resort to a way of better understanding as it motivates them to have recourse to "creative expression, and a nonthreatening way for struggling students". This consequence of this strategy helps the researcher to plan his/her next phase.

Brainstorming strategy also assists students to "write down everything they remember about a topic". Questions students feel confused and irritated can be raised to enable students to identify "how what they learned literally connects with what they already know by creating a concept map".
Jigsawing strategy helps students to break down larger units into small puzzles, helping them to collaboratively solve existing problems. In effect, Jigsawing encourages "students in groups to gather and share questions they have... in groups, and then choose one question that they weren't able to answer among themselves with the whole class".

Making use of the above reflective teaching strategies, students can exchange ideas, forming assumptions and gaining prerequisites about the essays they are asked to write about. The next session, the researcher first nominates a student and asks him/her to read his/her written essay painstakingly, and then she asks other members of the experimental group to reflect (in terms of the above mentioned reflective strategies) on what the student has written. This experiment has been implemented for eight sessions ending with a posttest, designed to measure students' achievement in correlation with the stated strategies.

\subsection{Method}

To attain the aims stated at the beginning of the study, the researcher utilizes an amalgamation of qualitative and quantitative method to analyze the data collected from the application of reflective teaching strategies in developing students' writing ability and the responses to tests (pre- test and posttests). Numerical tools are utilized to account for the objective analysis of these responses, supported by tables and figures.

\section{DATA COLLECTION AND RESULTS}

Data collection is drawn from two sources: (i) researcher's observation of the eight sessions as she watched the students performing activities of writing following reflective teaching strategies and (ii) tests (pretest and post- test); a pretest is administered to two sections (A and B ); twelve students of each section are chosen to be one as a control group and the other as an experimental group. The two groups involve students whose marks are nearly equal. The rate of grading the control group in the pretest is \% 
49.41 and the rate of grading the experimental group is $\% 49$.

The control group is taught writing by their teacher, following the conventional way of teaching writing; they are given topics and asked to write essays on these topics at homes. The next lecture students are required to read their essays and their teacher attempts to correct some mistakes and errors his students committed. The same routine is followed through the coming lectures.

The experimental group is taught writing by the researcher following the reflective teaching strategies mentioned above. She keeps observing the students for eight sessions following the same procedures. Meanwhile, she notices that students have been gradually developing in their writing as they begin to think critically while writing their assignments. This fact is obviously demonstrated in their degrees of the posttest. The difference between pretest (\% 49) and posttest $(77 \%)$ of the experimental group is somehow high constituting (\%28) while the difference between the pretest $(\%$ 49.4) and posttest (\%54. 8) of the control group is little (i.e. \%5.4). The students' scores of the pretest and posttest are shown in the following tables:

Table 1: Pretest and Posttest of the Control Group

\begin{tabular}{|l|l|l|}
\hline Control Group & \multicolumn{1}{|c|}{ Pretest } & Posttest \\
\hline Student 1 & $\% 24$ & $\% 30$ \\
\hline Student 2 & $\% 32$ & $\% 45$ \\
\hline Student 3 & $\% 42$ & $\% 50$ \\
\hline Student 4 & $\% 46$ & $\% 50$ \\
\hline Student 5 & $\% 51$ & $\% 55$ \\
\hline Student 6 & $\% 53$ & $\% 56$ \\
\hline Student 7 & $\% 54$ & $\% 57$ \\
\hline Student 8 & $\% 56$ & $\% 57$ \\
\hline Student 9 & $\% 58$ & $\% 59$ \\
\hline Student 10 & $\% 58$ & $\% 60$ \\
\hline Student 11 & $\% 59$ & $\% 70$ \\
\hline Student 12 & $\% 60$ & $\% 59$ \\
\hline Total & $\% 49.4$ & \\
\hline
\end{tabular}


Table 2: Pretest and Posttest of the Experimental Group

\begin{tabular}{|c|c|c|}
\hline Control Group & Pretest & Posttest \\
\hline Student 1 & $\% 26$ & $\% 57$ \\
\hline Student 2 & $\% 36$ & $\% 59$ \\
\hline Student 3 & $\% 41$ & $\% 61$ \\
\hline Student 4 & $\% 43$ & $\% 67$ \\
\hline Student 5 & $\% 50$ & $\% 80$ \\
\hline Student 6 & $\% 50$ & $\% 79$ \\
\hline Student 7 & $\% 54$ & $\% 82$ \\
\hline Student 8 & $\% 55$ & $\% 80$ \\
\hline Student 9 & $\% 57$ & $\% 80$ \\
\hline Student 10 & $\% 58$ & $\% 94$ \\
\hline Student 11 & $\% 58$ & $\% 88$ \\
\hline Student 12 & $\% 60$ & $\% 93$ \\
\hline Total & $\% 49$ & $\% 77$ \\
\hline
\end{tabular}

To provide a more illustrative picture of the difference between the two groups (control and experimental) in the pretest and posttest, the following figures give the score of each student in these two tests focusing on the development in score that each student achieves in writing ability. 


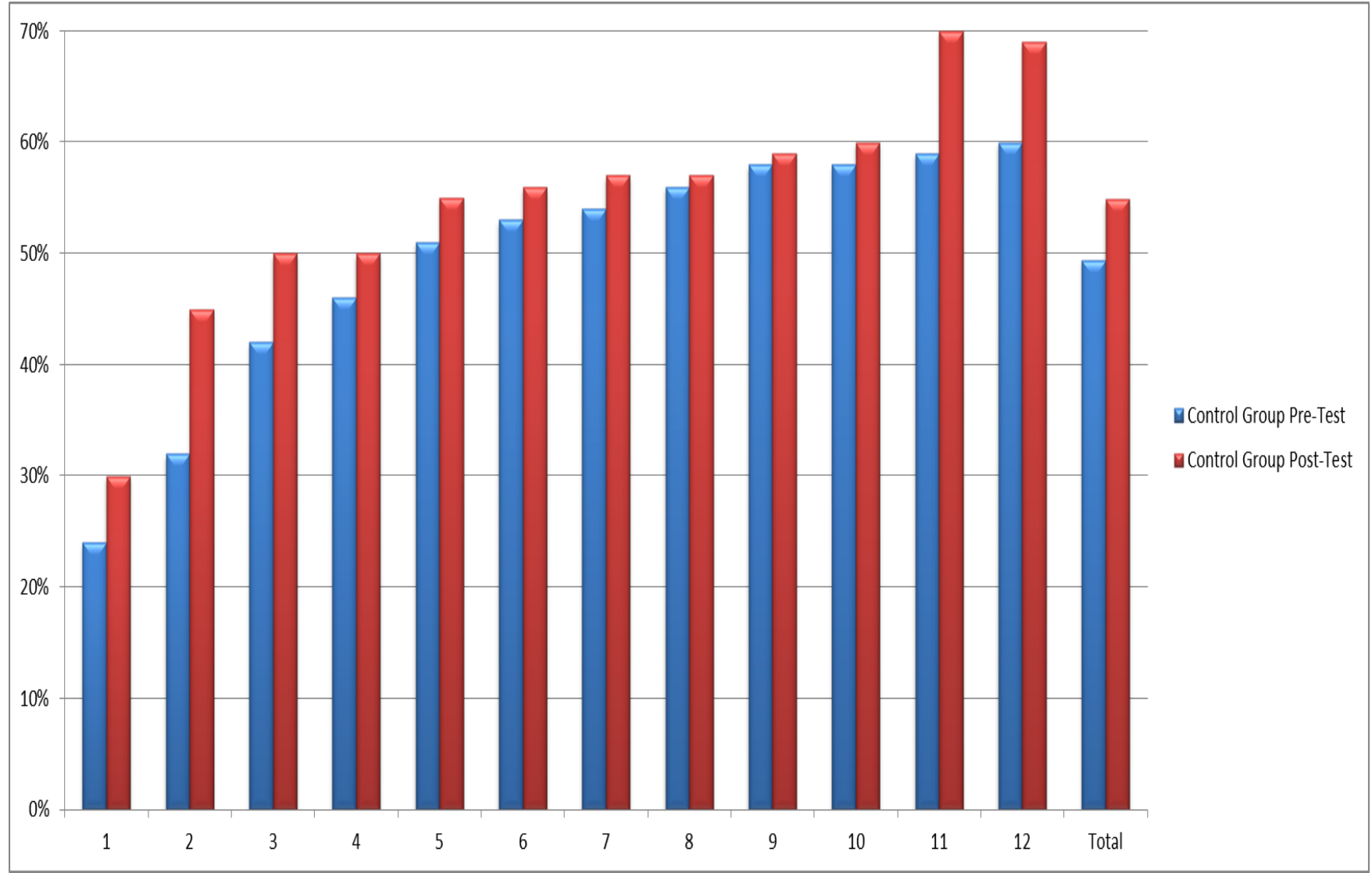

Figure 1: Pretest and posttest of the Control Group 


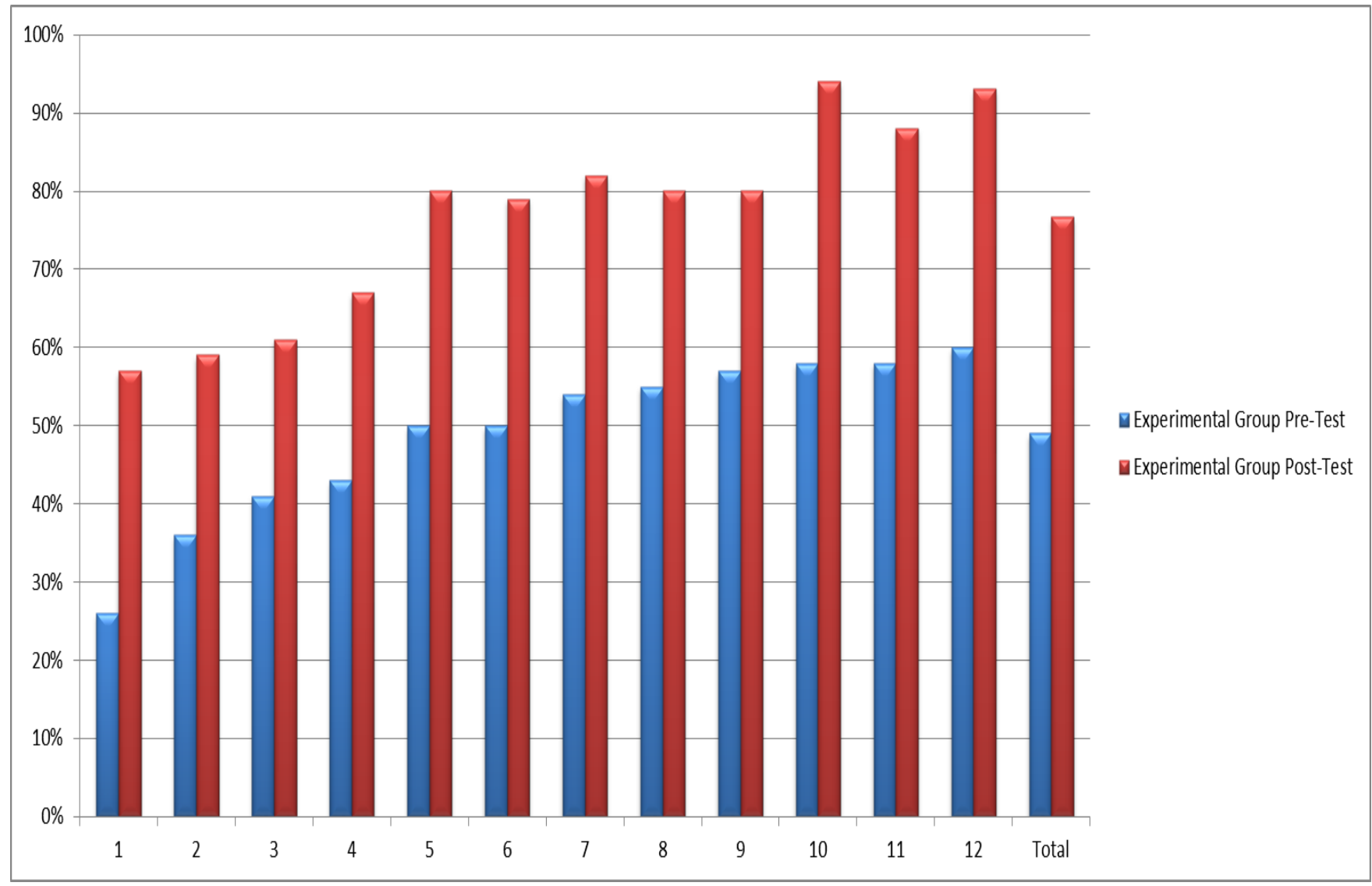

Figure 2: Pretest and posttest of the Experimental Group

\section{CONCLUSION}

Since two instruments (observation and tests) are employed to reveal the effect of reflective teaching strategies on students' performance in writing essays, the findings are of two types. Through observation, the researcher notices that utilizing these strategies leads to the following concluding points:

1. Giving students topics to be discussed and written about may help them to take part in peer and cooperative discussions and disputes and through mapping, they connect between what they have acquired and they previously know.
2. Reading an assignment by a student before the class may help other students to identify their mistakes and attempt to correct them and even not to repeat them.

3. Reflecting on students' writing assignments can create a non-threatening atmosphere, particularly for fraught students. It encourages them to exchange ideas with their peers and formulate assumptions and obtaining requisites about what to include in their writing. This may activate their critical thinking about what they write.

4. Brainstorming stimulates students to collect preinformation about the topic they want to write about, recall all the details required and talk about actual 
events in real life. In fact, it triggers their schemas of the scenes and activities involved.

5. It has been observed that appealing to reflective teaching strategies can create a cooperative setting which encourages student's sense of responsibility and an entertaining learning atmosphere. Students can share questions and find answers through cooperating with one another, and this motivates cooperative learning. Incidentally, teachers can identify what their students need to improve their writing ability and to plan for the coming lectures.
The results of the pretest and posttest have shown that the students of experimental group perform better than those of the control group in the posttest, and they achieve scores higher than those of control. Even, the difference in scores between the two groups indicates that the students of the experimental group have developed greater than those of the control group. This affirms the impact of reflective teaching strategies on enhancing students' writing ability.

\section{REFERENCES}

Bailey, K. M. (1990). "Diary Studies in Teacher Education Programs”. In Richards, J.C. and Nunan, D. ( eds.) Second Language Teacher Education, New York: CambridgeUniversity Press.

Bailey, K. and Nunan, D. (1996) Voices from the Language Classroom: Qualitative Research in Second LanguageEducation. Cambridge: Cambridge University Press.

Bailey W. M., Erickson, L., Hansen L. and Young Janet (2001). "'Paradise Unrealized: Teacher Educators and the Costs and Benefits of School/University Partnerships". Journal of Teacher Education. Vol. 10 ,No.(50),pp.5: 381.

Mohammad, N. H. Neflective Practitioner".https://www.academia.edu/12236381/REFLECTIVE_PRACTITIONER.

Hatcher, J. A. and Bringle, R. G. (1996). "Reflection Activities for the College Classroom". https://digitalcommons.unomaha.edu/cgi/ viewcontent. cgi? article=1064\&context =slceeval.

Bartlett, L. (1990).'Teacher Development through Reflective Teaching”, InRichards J. C. and Nunan D. (eds.).Second Language Teacher Education, New York: Cambridge University Press.

Dewey, J. (1933). How We Think. Lexington, MA: Health.

Fox, J. (2004)."Curriculum Design: Does it Make a Difference?" Contact, Vol.30, No.(2), pp. 1-4.

Larrivee, B. and Cooper. J. M. (2006). An Educator's Guide to Teacher Reflection. Boston: Houghton Mifflin Company.

Merryfield, S. (1993). "Reflective Teaching and Competence".In Pollard, A. and Tann, S. (eds.) Reflective Teaching in the Primary School: A Handbook for the Classroom London: Cassell.

Moore, A. (2007). "Beyond reflection: contingency, idiosyncrasy and reflexivity in initial teacher education". In Hammersley, M. (ed.), Educational research and evidence-based practice. London: Cromwell Press. 
Powell, J.P. (1985). "Autobiographical learning". In Bond, D. and Keogh, R. and Walker, D. (eds). Reflection: Turning Experience into Learning. London: Kogan Page. (pp. 41-51).

Richards, J. C. (1990).The Language Teaching Matrix. Cambridge: Cambridge University Press.

Richards, J. C. and Lockhart, C. (1994). Reflective Teaching in Second Language Classrooms. Cambridge: Cambridge University Press.

Schon, D. A. (1996)The Reflective Turn: Case Studies in and on Educational Practice. New York: Teachers Press, Columbia University.

Taggart, G. L. and Wilson, A. P. (2005). "Becoming a Reflective Teacher ". In. Taggart, G.L and Wilson, A. P. (eds.) Promoting Reflective Thinking in Teachers: 50 Action Strategies. California: Corwin Press.

Wallace, M.(1991). Training Foreign Language Teachers. Cambridge: Cambridge University Press.

Wilson, N. (1990) Research Methods in Education and the Social Sciences, Buckingham: OUP.

York, D. S., Sentner, S. M., and Forlenza-Bailey, A. (2006)."An Examination of the Construct of Critical Reflection: Implications for Teacher Education Programming in the 21st Century". Journal of Teacher Education. Vol. 51, No. (1), pp. 39-48.

Zeichner, K. M. and Liston, D. P. (1996). Reflective Teaching: An Introduction.Mahwah, NJ: Lawrence Erlbaum Associates, Publishers. 